Original Article

\title{
EFFECT OF COMMON CARP AND AFRICAN CATFISH OILS ON RATS FED ON HIGH-FAT DIET
}

\author{
MEDHAT MOSTAFA ABOZID ${ }^{1 *}$, HOSSAM ZEIN ${ }^{2}$, AMER ABD EL-HALEM ${ }^{3}$
}

${ }^{1}$ Biochemistry Department, Faculty of Agriculture, Menoufia University, Shibin El-Kom, Egypt, ${ }^{2}$ Special Food and Nutrition Department, Food Technology Research Institute, Agricultural Research Center, Giza, Egypt, ${ }^{3}$ Department of Lab, Shibin El-Kanater Hospital, Ministry of Health, Egypt

Email: medhatabozid@gmail.com

Received: 02 Nov 2017 Revised and Accepted: 21 Dec 2017

ABSTRACT

Objective: The present study was designed to study the effect of common carp and African catfish oils on the lipid profiles and liver functions in rats fed on high-fat diets, also fatty acids were assessed in both oils by gas-liquid chromatography (GLC).

Methods: A biological experiment on rats was designed to raise fat in the diet and to study the effect of treatment with common carp and African catfish oils for $6 \mathrm{w}$ (by the stomach tube) and then evaluate their impact on blood lipid profile and liver functions (Alanine transaminase [ALT], aspartate transaminase [AST] total protein and albumin).

Results: GLC analysis of fatty acids (FAs) revealed the presence of oleic, palmitic, palmitolic, and linoleic acids more than $70 \%$ from total fatty acids in two oils. High-fat diet resulted in a significant increase in plasma lipid profile as well as liver functions. The treatment of rats fed high fat diets with common carp and African catfish oils resulted in a significant decrease in levels of triglycerides (TGs), total cholesterol (TC), low-denisty lipioprotein cholesterol (LDL-c), total cholesterol (TC)/high-denisty lipoprotein cholesterol (HDL-c) and TGs/HDL-c ratios compared with positive control group, while the same treatment with these oils resulted in a significant increase in HDL-c levels compared with positive control group. The intake of common carp and African catfish oils also significantly reduced ALT and AST activities compared with positive control group. Common carp and African catfish oils showed an anti-hyperlipidemic effect in rats feeding on hypercholesterolemic diets.

Conclusion: It could be concluded that these fish oils have a promising role in reducing the harmful effects of high-fat diets.

Keywords: Common carp, African catfish, Oils, High fat diet, Lipid profile

(c) 2018 The Authors. Published by Innovare Academic Sciences Pvt Ltd. This is an open access article under the CC BY license (http://creativecommons.org/licenses/by/4.0/) DOI: http://dx.doi.org/10.22159/ijpps.2018v10i2.23452

\section{INTRODUCTION}

Excess fats in our diets are a major source of cardiovascular diseases, atherosclerosis, obesity and fatty liver [1-6]. Many previous studies have confirmed that dieting play an important role in lowering blood lipids and reducing the harmful effects of saturated fat and cholesterol [7-10]

Fish consumption has increased in recent years because of the critical increment in the populace. Fish are important sources of high-value protein, essential fatty acids (omega 3 fatty acids), important minerals (selenium and iodine) and vitamins (vitamin D and vitamin B-12) [11]. Commonly, freshwater species show a more prominent ability to desaturate and elongate fatty acids in contrast with their marine partners which are accounted for to be generally wasteful in this process [12-13].

Common carp (Cyprinus carpio) and African catfish (Clarias gariepinus) have attracted attention as a promising species for fish culture in different countries and also in Egypt due to its rapid growth and easiness of breeding [14-15]. Many researchers [16-18] have studied the fats found in both two fish species and found that they contain a high amount of unsaturated fatty acids, especially oleic acid (omega 9) and linoleic acid (omega 6), as well as not a few amount of omega 3 fatty acids family [ $\alpha$-linolenic, eicosapentaenoic (EPA) and docosahexaenoic acids (DHA)]. In this study, we focused on identify of fatty acid profiles and fat soluble vitamins in common carp and African catfish oils and studying the hypolipidemic effect of these oils.

\section{MATERIALS AND METHODS}

\section{Sample procedure}

The fishes were identified by the exterior shape in the department of Poultry production, Faculty of Agriculture, Menoufia University.

Samples of African catfish (Clarias garipinus $L$ ), and common carp (Cyprinus carpio L) were obtained from a local fish market
(Menoufia, Egypt) during the autumn of 2016. They were eviscerated, washed and immediately transported to the laboratory in ice containing boxes. Fresh fish were washed with tap water three times to expel blood, they were then arranged utilizing basic family rehearses, for example, expelling head, spine, skin, tail and balance yielding two filets. The fillets parts of African catfish and common carp were cut into small pieces, allowed to dry in a hot air oven at 65 ${ }^{\circ} \mathrm{C}$ for $96 \mathrm{~h}$, grounded into a powder state using a commercial blender.

\section{Chemicals and reagents}

Sodium sulphate, sodium hydroxide, sodium chloride, potassium hydroxide, ascorbic acid, hexane, isopropanol, chloroform, methanol, ethanol and acetonitrile were obtained from El-Gomhoria Company, cairo, Egypt.

Kits of triglycerides (TGs), total cholesterol (TC) and HDL-c, were obtained from Spinreact Co. Girona (Spain) and kits for total protein, albumin and ALT, AST enzymes activity were obtained from Diamond Company, Cairo, Egypt.

\section{Lipid analysis}

\section{Lipid extraction}

Lipids from fish tissues were extracted by the hexane-isopropanol method [19]. Samples (5 g) were homogenized in $75 \mathrm{ml}$ hexane: isopropanol $(3: 2, \mathrm{v} / \mathrm{v})$ using an Wise-Tis homogenizer (Daihan scientific company, Korea). Non-lipids were removed by adding 32.5 $\mathrm{ml} 6.67 \%$ sodium sulphate to each sample. Samples were shaken, centrifuged and evaporated. Dried samples were dissolved in chloroform and stored in- $20{ }^{\circ} \mathrm{C}$.

Preparation of fatty acids methyl esters (FAME)

Extracted lipids were methylated following the procedure of [20]. 2 $\mathrm{ml} 0.01 \mathrm{M} \mathrm{NaOH}$ in dry methanol was added to each lipid sample. 
The samples were shaken then heated for 10 min on a heating block at $60^{\circ} \mathrm{C}$. Next $3 \mathrm{ml} \mathrm{BF}_{3}$ reagent $(20 \%$ boron trifluoride-methanol complex) was added and the samples were reheated for $10 \mathrm{~min}$. The samples were then cooled and $2 \mathrm{ml} 20 \% \mathrm{NaCl}$ and $2 \mathrm{ml}$ hexane were added. The test tubes were shaken vigorously then centrifuged for 5 min at $2500 \mathrm{rpm}$ at $18{ }^{\circ} \mathrm{C}$. The FAME was transferred to small test tubes and evaporated under nitrogen gas. The dried samples were dissolved in hexane and stored at- $20{ }^{\circ} \mathrm{C}$ until gas chromatography analyses.

\section{Gas chromatography (GC)}

Fatty acids methyl esters were analysed with a gas chromatograph Perkin Elmer Auto System XL (National Research Center, Cairo, Egypt) equipped with flame ionization detector. The samples $(1 \mu \mathrm{l})$ were injected by autosampler, split mode. The split ratio $1: 10$ was used. The column temperature was programmed to start at $158^{\circ} \mathrm{C}$ for $5 \mathrm{~min}$ and then increase at $2^{\circ} \mathrm{C} / \mathrm{min}$ from $158^{\circ}$ to $220^{\circ} \mathrm{C}$ and remain at $220^{\circ} \mathrm{C}$ for $10 \mathrm{~min}$. Injector and detector temperatures were $230^{\circ}$ and $250^{\circ} \mathrm{C}$, respectively. Fatty acids were identified by comparison with the standard mixture and retention times. Peak areas were integrated. The carrier gas was helium $(23 \mathrm{~cm} / \mathrm{s}$, flow rate $0.7 \mathrm{ml} / \mathrm{min}$ ).

\section{High-performance liquid chromatography (HPLC) analysis for retinol, cholecalciferol and $\alpha$-tocopherol}

Retinol, cholecalciferol and $\alpha$-tocopherol were determined with HPLC using a Shimadzu LC 20 AT, SPD-20 UV Visible detector and SIL 20A autosampler. The HPLC column was a TM $5 \mu \mathrm{M} \mathrm{C18,} 25 \mathrm{~cm} \mathrm{x}$ $4.6 \mathrm{~mm}$. Identification and quantification were done by using external standards. For the analysis of retinol, cholecalciferol and $\alpha$ tocopherol a modified method by [21] was used. $20 \mathrm{mg}$ lipid was extracted in $2 \mathrm{ml}$ ethanol then $1.2 \mathrm{ml}$ of $20 \%$ ascorbic acid solution, $0.6 \mathrm{ml}$ methanol and $1.2 \mathrm{ml}$ of $\mathrm{KOH}$-water $(1: 1)$ were added to each tube. After saponification and cooling, retinol, cholecalciferol and $\alpha$ tocopherol were extracted in 2 times $4 \mathrm{ml}$ of hexane. The hexane- vitamin solution was evaporated under nitrogen gas and diluted with the mobile phase. The mobile phase used consisted of $95 \%$ metanol: acetonitrile (1:1) and 5\% chloroform with a flow rate of 1.2 $\mathrm{ml} / \mathrm{min}$. $\alpha$-tocopherol and retinol were detected with excitation wavelengths of 290 and $344 \mathrm{~nm}$, respectively, and with emission wavelengths of 327 and $472 \mathrm{~nm}$, respectively. Cholecalciferol was monitored by UV detection at $265 \mathrm{~nm}$.

\section{In vivo study}

\section{Animals, diets and blood sampling}

The work was carried out at animal house in the Research Institute of Ophthalmology (Giza, Egypt). To study the effect of common carp and African catfish oils on lipid profiles and liver functions of albino rats, thirty-two male albino rats (weighting between 150 and $170 \mathrm{~g}$ ) were used for the investigation. The rats were obtained from the Research Institute of Ophthalmology (Giza, Egypt).

The rats were fed ad lipitum on standard diet and water for two weeks as an adaption period. They were housed individually in stainless steel cages and divided into four groups of eight animals. Negative control group (NC) was fed on standard diet (SD); while the other three groups fed the hypercholesterolemic diet (HCD) was designed as reported by [22] as follow: positive control group (PC) kept without any treatments, common carp oil group (CCO) treated by stomach tube $(5 \mathrm{~g} / \mathrm{Kg}$ body weight as daily basis) with common carp oil and African catfish group (ACO) treated by stomach tube ( $5 \mathrm{~g} / \mathrm{Kg}$ body weight as daily basis) with African catfish oil.

Their food intake was monitored daily and all the rats fasted for $12 \mathrm{~h}$ before blood sampling. The blood samples were drawn from eye plexuses after six weeks. The rats were anaesthetized using diethyl ether. The weight gain of the rats was recorded weekly.

Blood samples were collected in tubes containing ethylene diaminetetraacetic acid (EDTA) and centrifuged at $3600 \mathrm{rpm}$ at $5^{\circ} \mathrm{C}$ for $15 \mathrm{~min}$, and the plasma was transferred to new tubes and stored at $4{ }^{\circ} \mathrm{C}$.

Table 1: Compositions of standard diet (SD) and hypercholesterolemic diet (HCD)

\begin{tabular}{lll}
\hline Ingredients (\%) & SD & HCD \\
\hline Starch & 47 & 41.25 \\
Sucrose & 23 & 17.5 \\
Casein & 12.5 & 12.5 \\
Corn oil & 10 & - \\
Salts mixture & 3.5 & 3.5 \\
Vitamins mixture & 1 & 1 \\
Fiber & 3 & 3 \\
Coconut oil & - & 20 \\
Cholesterol & - & 1 \\
Cholic acid & - & 0.25 \\
\hline
\end{tabular}

\section{Plasma biochemistry}

Plasma levels of triglycerides (TGs) were analyzed according to [23]. The total cholesterol (TC) was analyzed according to [24]. HDL-c was determined and LDL-c was calculated according to [25]. Total cholesterol/HDL-c and TGs/HDL-c ratios were calculated. ALT and AST activities were measured according to the method described by [26]. Total protein was determined according to [27]. Albumin was determined according to [28].

\section{Statistical analysis}

The results of the animal experiments were expressed as the mean \pm SD and they were analyzed statistically using the one-way analysis of variance (ANOVA) followed by Duncan's test.

\section{RESULTS AND DISCUSSION}

\section{Fatty acid profile of common carp and African catfish oils:}

Fish lipid content and fatty acids composition varies significantly depending on many factors such as fish species, season, locality, and life phase [29-31].
The fatty acid composition of common carp and African catfish oils is presented in table 2 . These data denoted that, in the common carp oil seventeen fatty acids were identified, whereas eighteen fatty acids were identified in the African catfish oil. The most dominant fatty acids in both fish oils were oleic (C18:1 n-9), palmitic (C16:0) and linoleic (C18:2 n-6) and they presented the following distribution oleic $>$ palmitic $>$ linoleic in common carp oil; while the distribution in African catfish oil were palmitic > oleic $>$ linoleic. These results are in agreement with [32-34] for catfish oil and [35-36] for common carp oil.

Linoleic acid (C18:2 n-6) was the primary n-6 fatty acid, 18.65 and $14.66 \%$ for common carp and African catfish oils, respectively. Omega 3 fatty acids (n-3 fatty acids) identified in common carp oil were $\alpha$ linolenic acid (1.68\%), EPA (2.44\%), DHA (2.35\%) and eicosatrienoic acid $(0.85 \%)$ which are in agreement with [37-38]; while in African catfish oil were DHA (2.99\%), EPA (2.34\%), $\alpha$-linolenic acid (1.78\%) and eicosatrienoic acid $(0.69 \%)$ which are in line with data observed for catfish oil in earlier investigations [33-34].

There are two important reasons for variation in EPA and DHA contents in fish oils the first is: fish diet and second is: fish are wild or fish farms [39]. 
The presence of EPA, DHA and arachidonic acid in two fish oils in current study can be explained in light of the concept of [40-41] who suggested that freshwater fishes have a high capacity for bioconversion of $\alpha$-linolenic acid (C18:3 n-3) and linoleic acid (C18:2 $\mathrm{n}-6)$ into higher unsaturated fatty acid EPA, DHA and arachidonic acid, respectively.

Table 2: Levels of fatty acids (FAs) (\%) in common carp (CC) and African catfish (AC) oils

\begin{tabular}{|c|c|c|c|}
\hline \multicolumn{2}{|l|}{ FAs } & \multirow{2}{*}{$\begin{array}{l}\text { CC oil } \\
1.11 \pm 0.021\end{array}$} & \multirow{2}{*}{$\begin{array}{l}\text { AC oil } \\
3.41 \pm 0.16\end{array}$} \\
\hline C14:0 & Myristic acid & & \\
\hline C16:0 & Palmitic acid & $19.25 \pm 0.11$ & $23.75 \pm 0.12$ \\
\hline C18:0 & Stearic acid & $6.33 \pm 0.11$ & $4.98 \pm 0.1$ \\
\hline C20:0 & Arachidic acid & $0.44 \pm 0.05$ & $1.21 \pm 0.095$ \\
\hline C22:0 & Docosanoic acid & $0.25 \pm 0.04$ & $0.77 \pm 0.056$ \\
\hline$C: 24: 0$ & Lignoceric acid & ND & $0.88 \pm 0.055$ \\
\hline \multicolumn{2}{|c|}{$\Sigma$ Saturated fatty acids } & $27.39 \pm 0.33$ & $34.99 \pm 0.58$ \\
\hline C16:1 (n-9) & Palmitolic acid & $6.23 \pm 0.95$ & $15.63 \pm 0.025$ \\
\hline C18:1 (n-9) & Oleic acid & $33.56 \pm 0.49$ & $19.87 \pm 0.08$ \\
\hline $\mathrm{C} 20: 1(\mathrm{n}-9)$ & Gadoleic acid & $2.83 \pm 0.15$ & $0.57 \pm 0.05$ \\
\hline $\mathrm{C} 22: 1(\mathrm{n}-9)$ & Erucic acid & $0.47 \pm 0.06$ & $0.38 \pm 0.04$ \\
\hline \multicolumn{2}{|c|}{$\Sigma$ Monounsaturated fatty acids } & $43.09 \pm 0.38$ & $36.45 \pm 0.15$ \\
\hline C18:2 (n-6) & Linoleic acid & $18.65 \pm 0.092$ & $14.66 \pm 0.1$ \\
\hline C18:3 (n-6) & $\gamma$-Linolenic acid & $0.37 \pm 0.051$ & $0.87 \pm 0.03$ \\
\hline $\mathrm{C} 20: 3(\mathrm{n}-6)$ & Dihomo $\gamma$-linolenic acid & $1.07 \pm 0.05$ & $1.11 \pm 0.025$ \\
\hline $\mathrm{C} 20: 4(\mathrm{n}-6)$ & Arachidonic acid & $1.13 \pm 0.55$ & $1.66 \pm 0.09$ \\
\hline \multicolumn{2}{|c|}{$\Sigma$ n-6 fatty acids } & $21.22 \pm 0.047$ & $18.31 \pm 0.25$ \\
\hline C18:3 (n-3) & $\alpha$-linolenic acid & $1.68 \pm 0.095$ & $1.78 \pm 0.045$ \\
\hline $\mathrm{C} 20: 3(\mathrm{n}-3)$ & Eicosatrienoic acid & $0.85 \pm 0.04$ & $0.69 \pm 0.035$ \\
\hline C20:5 (n-3) & Eicosapentaenoic acid (EPA) & $2.44 \pm 0.044$ & $2.34 \pm 0.03$ \\
\hline $\mathrm{C} 22: 6(\mathrm{n}-3)$ & Docosahexaenoic acid (DHA) & $2.35 \pm 0.12$ & $2.99 \pm 0.14$ \\
\hline \multicolumn{2}{|c|}{$\sum$ n-3 fatty acids } & $7.32 \pm 0.29$ & $7.79 \pm 0.24$ \\
\hline
\end{tabular}

Values are mean \pm standard deviation (SD) of three samples.

\section{Fat-soluble vitamins composition of common carp and African catfish oils}

The amounts of retinol, cholecalciferol, and $\alpha$-tocopherol contents are presented in table 3 in $\mu \mathrm{g} / 100 \mathrm{~g}$; the results were expressed as mean and standard deviations.

Common carp oil contained a large amount $(1576 \mu \mathrm{g} / \mathrm{g})$ of $\alpha$ tocopherol, while low levels of retinol $(33.63 \mu \mathrm{g} / \mathrm{g})$ and cholecalciferol $(17.49 \mu \mathrm{g} / \mathrm{g})$ were measured. In African catfish oil distribution of fat-soluble vitamins were $\alpha$-tocopherol $(1240 \mu \mathrm{g} / \mathrm{g})$ followed by retinol $(17.97 \mu \mathrm{g} / \mathrm{g})$ and cholecalciferol $(8.5 \mu \mathrm{g} / \mathrm{g})$. This means that both two fish oils are good sources of $\alpha$-tocopherols which may play important role in protecting unsaturated fatty acids from peroxidation.
These data denoted that the three fat-soluble vitamins (retinol, cholecalciferol, and $\alpha$-tocopherol) were found in lower amounts in African catfish oil compared with common carp oil, these results run with published by $[34,42,43]$; who confirmed a similar relationship between the amounts of those vitamins in the two types of fish.

In comparison with the current study [44] found fewer amounts for the same vitamins (retinol, cholecalciferol, and $\alpha$-tocopherol). The difference in results may be attributed to the difference in the type of feeding, which in turn depends on the livelihood of the fish in a natural way or on fish farms. Wild fish feeds on benthos and plankton, which is a good source of fat-soluble vitamins, while fish farms foods are rich in carbohydrates [45].

Table 3: Total content of fat soluble vitamins in common carp (CC) and African catfish (AC) oils

\begin{tabular}{|c|c|c|}
\hline \multirow[t]{2}{*}{ Vitamins } & \multicolumn{2}{|c|}{ Total content $(\mu \mathrm{g} / \mathrm{g})$} \\
\hline & CC oil & AC oil \\
\hline Retinol & $33.63 \pm 1.77$ & $17.97 \pm 1.25$ \\
\hline Cholecalciferol & $17.49 \pm 0.78$ & $8.5 \pm 0.9$ \\
\hline$\alpha$-Tocopherol & $1576 \pm 95.01$ & $1240 \pm 66.64$ \\
\hline
\end{tabular}

Values are mean \pm standard deviation (SD) of three samples.

Impact of common carp and African catfish oils supplementation on the plasma lipid profile

The control group (CC) gave the lowest levels in all lipid estimates tested. Groups treated with common carp (CCO) and African catfish (ACO) oils showed a significant reduction in levels of TGs, TC, LDL-c, TC/HDL-C and TGs/HDL-c ratios compared with positive control group (PC). HDL-c produced a different response, PC group had the lowest level followed by ACO and then CCO groups (table 4).

Many researchers [22, 46-50] have observed the elevation in the ratios of TC/HDL-c and TGs/HDL-c in experimental animals fed high fat and high cholesterol diets and cholesterol, which are believed to be closely related to atherosclerosis. In current study (table 4), it can be noticed that the PC group showed significantly higher levels of blood lipids compared with the NC group. On the other hand, CCO and ACO groups indicated bring down levels of lipid profile parameters which are in harmony with many researchers have addressed the relationship between the use of diets rich in oleic and linoleic acids and reduce the levels of lipid profile parameters [7, 5153]; common carp oil and African catfish oil are characterized by high content of oleic (33.56 and $19.87 \%$, respectively) and linoleic (18.65 and $14.66 \%$, respectively). 
Table 4: Plasma lipid profile parameters of rats fed different experimental diets

\begin{tabular}{llll}
\hline Groups & NC & PC & CCO \\
\cline { 1 - 3 } Parameters & & & ACO \\
\hline TGs (mg/dl) & $126.25 \pm 3.8 \mathrm{a}$ & $314.75 \pm 5.7 \mathrm{~d}$ & $241.5 \pm 4.1 \mathrm{~b}$ \\
TC $(\mathrm{mg} / \mathrm{dl})$ & $106.62 \pm 3.9 \mathrm{a}$ & $248.87 \pm 6.1 \mathrm{~d}$ & $192.12 \pm 4.2 \mathrm{~b}$ \\
HDL-c (mg/dl) & $31.87 \pm 3.6 \mathrm{a}$ & $54.62 \pm 3.5 \mathrm{~b}$ & $74.75 \pm 4.2 \mathrm{~d}$ \\
LDL-c (mg/dl) & $49.5 \pm 3.6 \mathrm{a}$ & $131.3 \pm 7.3 \mathrm{~d}$ & $69.07 \pm 5 \mathrm{~b}$ \\
TC/HDL-c & $3.38 \pm 0.35 \mathrm{~b}$ & $4.57 \pm 0.29 \mathrm{c}$ & $215 \pm 4.8 \mathrm{c}$ \\
TGs/HDL-c & $4 \pm 0.44 \mathrm{~b}$ & $5.78 \pm 0.39 \mathrm{c}$ & $2.58 \pm 0.14 \mathrm{a}$ \\
\hline
\end{tabular}

Values represent means \pm SD obtained from 8 rats, Means in the same row followed by the same letters do not differ significantly, and when the means followed by different letters differ significantly at $(\mathrm{p} \geq 0.01)$

Also, the reduced effect of plasma lipid profile levels can be correlated with common carp and African catfish oils with a significant content of fatty acids EPA, DHA (omega- 3 family), it is possible to confirm the previous recommendations of [54-56] who emphasized that omega-3 fatty acids play an important role in reducing the risk of atherosclerosis caused by elevated blood lipids. The data in the table (4) showed that CCO group has better reduction in TGs, TC, LDL-c, TC/HDL-c and TGs/HDL-c ratios than ACO group, which may be due to the high content of oleic, linoleic acids in common carp oil compared with African catfish oil.

The hypolipidemic effect may be attributed to the presence of high amounts of $\alpha$-tocopherol (table 3) in both fish oils, as noted by a number of researchers in previous studies [7, 57].

There are many explanations that may explain how fish oils improve lipid profile such as changes in LDL production and lipoprotein composition [58]. Omega 3 fatty acids (EPA and DHA) prevent triglycerides synthesis [59]. Moreover, polyunsaturated fatty acids activate the enzymes involved in $\beta$-Oxidation [60].

Impact of common carp and African catfish oils supplementation on liver functions

The obtained results in table (5) clarified that PC group showed the highest levels of AST and ALT activities (39.5 and $25.35 \mathrm{U} / \mathrm{l}$ respectively) compared other groups.
Such findings coincide with that obtained by [6, 7, 61, 62], who found that when experimental animals feed on high-fat diets, this leads to a significant increase in both AST and ALT activities compared with animals feed on normal diets. While those results don't agree with [22]; which may be explained by different feeding period on high-fat meals, where in the current study six weeks, while in the study referred to one month only.

Increases in plasma AST and ALT activities are usually indicative of possible liver damage or fatty liver. Although the fatty liver (FL) has not been classified as a disease, but many recent studies have shown the relationship of FL with many health problems such as atherosclerosis, kidney disease, colon cancer and osteoporosis [6365].

Treatment with common carp and African catfish oils induced a significant decrease in AST and ALT enzymes activities compared with positive control group. These results are consistent with many previous studies $[7,10]$ that have indicated the vital role played by diets containing unsaturated fatty acids in improving the levels of liver enzymes. Common carp and African catfish oils have high contents of unsaturated fatty acids (oleic and linoleic acids), in addition to their good amounts of omega 3 fatty acids. Therefore, both CCO and ACOgroups showed enhanced levels of AST and ALT in plasma, which might be because of the enhancing impact of these oils in lipid metabolism.

Table 5: Plasma liver function parameters of rats fed different experimental diets

\begin{tabular}{|c|c|c|c|c|}
\hline Groups & NC & PC & CCO & ACO \\
\hline \multicolumn{5}{|l|}{ Parameters } \\
\hline AST (U/l) & $24.87 \pm 1.03 \mathrm{a}$ & $39.5 \pm 1.6 \mathrm{c}$ & $31.7 \pm 1.09 \mathrm{~b}$ & $32.07 \pm 1.1 \mathrm{~b}$ \\
\hline $\operatorname{ALT}(\mathrm{U} / \mathrm{l})$ & $16.54 \pm 1.08 \mathrm{a}$ & $25.35 \pm 1.22 \mathrm{c}$ & $20.19 \pm 1.07 \mathrm{~b}$ & $21 \pm 1.58 \mathrm{~b}$ \\
\hline Total protein (g/dl) & $3.36 \pm 0.19 \mathrm{a}$ & $3.37 \pm 0.25 \mathrm{a}$ & $3.4 \pm 0.29 \mathrm{a}$ & $3.34 \pm 0.2 \mathrm{a}$ \\
\hline Albumin (g/dl) & $5.66 \pm 0.16 \mathrm{a}$ & $5.61 \pm 0.19 \mathrm{a}$ & $5.59 \pm 0.27 \mathrm{a}$ & $5.58 \pm 0.15 \mathrm{a}$ \\
\hline
\end{tabular}

Values represent means \pm SD obtained from 8 rats, Means in the same row followed by the same letters do not differ significantly, and when the means followed by different letters differ significantly at $(\mathrm{p} \geq 0.01)$

\section{CONCLUSION}

Common carp and African catfish oils significantly improve the negative effects of high-fat diets on plasma lipid profile levels as well as liver enzymes and these effects are mainly mediated by high amounts of unsaturated fatty acids and omega 3 fatty acids. Future studies need to assess the level of contamination of these species of fish in the local environment to recommend their use as an alternative to cold water fish characterized by high mercury content.

\section{ACKNOWLEDGMENT}

We gratefully acknowledge Prof. Dr. Shaban Negm Draz, Prof. Dr. Samir Abd El-Kader El-Kadousy and Prof. Dr. Samia Mahmoud Khalil (Biochemistry department, Faculty of Agriculture, Menoufia University) for their recommendations and advice during the research period.

\section{AUTHORS CONTRIBUTIONS}

Medhat M. Abozid developed the design of the experiment, carried out the biological experiment and wrote the manuscript. Hossam
Zein shared in the design and implementation of experiments. Amer Abd El-Halem carried out blood analysis.

\section{COMPETING INTERESTS}

The authors declare that there is no conflict of interests regarding the publication of this paper.

\section{REFERENCES}

1. Jayasooriya AP, Sakono N, Yukizaki C, Kawano M, Yamamoto K, Fukerda N. Effect of Momordica charantia powder on serum glucose levels and various lipid parameters in rats fed with cholesterol-free and cholesterol-enriched diets. J Ethnopharmacol 2000;72:331-6.

2. Rizvi F, Iftikhar M, George JP. Beneficial effects of fish liver preparations of sea bass (Lates calcarifer) versus gemfibrozil in high-fat-diet-induced lipid-intolerant rats. J Med Food 2003;6:123-8.

3. Matsuzawa N, Takamura T, Kurita S, Misu H, Ota T, Ando H. Lipid-induced oxidative stress causes steatohepatitis in mice fed an atherogenic diet. Hepatol 2007;46:1392-3. 
4. Ogawa T, Fujii H, Yoshizato K, Kawada N. A human-type nonalcoholic steatohepatitis model with advanced fibrosis in rabbits. Am J Pathol 2010;177:153-5.

5. Subramanian S, Goodspeed L, Wang S, Kim J, Zeng L, Ioannou GN. Dietary cholesterol exacerbates hepatic steatosis and inflammation in obese LDL receptor-deficient mice. J Lipid Res 2011;52:1626-5.

6. Toppo E, Darvin SS, Esakkimuthu S, Stalin A, Balakrishna K, Sivasankaran K, et al. Antihyperlipidemic and hepatoprotective effects of gardenin a in cellular and high fat diet fed rodent models. Chem-Biol Interact 2017;269:9-17.

7. Ramadan MF, Zayed R, Abozid MM, Asker MMS. Apricot and pumpkin oils reduce plasma cholesterol and triacylglycerol concentrations in rats fed a high-fat diet. Grasas Aceites 2011;62:443-52.

8. Abozid MM, Farid HE. The anti-fatty liver effects of guava leaves and pomegranate peel extracts on ethanol-exposed rats. J Biol Chem Environ Sci 2013;8:83-104.

9. Abozid MM, Ayimba E. Effect of omega 3 fatty acids family in human health-a review. Int J Adv Res 2014;2:202-11.

10. Abozid MM, Farid HE, EL-Sayed SM. Impact of flaxseed and oil extracted from Nile Tilapia waste on rats feed on a high fat diet. Int J Pharm Tech Res 2015;8:938-45.

11. Stolyhwo A, Kolodziejska I, Sikorski ZE. Long-chain polyunsaturated fatty acids in smoked Atlantic mackerel and baltic sprats. Food Chem 2006;94:589-95.

12. Tocher D, Zheng X, Schlechtriem C, Hastings N, Dick J, Teale A. Highly unsaturated fatty acid synthesis in marine fish: cloning, functional characterization, and nutritional regulation of fatty acyl $\Delta 6$ desaturase of atlantic cod (Gadusmorhua L.). Lipids 2006;41:1003-16.

13. Vagner M, Santigosa E. Characterisation and modulation of gene expression and enzymatic activity of delta- 6 desaturase in teleosts-a review. Aquaculture 2011;315:131-43.

14. Tokur B, Ozkutuk S, Atici E, Ozyurt G, Ozyurt CE. Chemical and sensory quality changes of fish fingers, made from mirror carp (Cyprinus carpio L., 1758), during frozen storage. Food Chem 2006;99:335-41.

15. Shourbela RM, Abd El-latif AM, Abd-El-Azem MA. Induced spawning of African catfish, using (GnRHa) combined with dopamine antagonists. BVMJ 2014;27:25-35.

16. Weber J, Bochi VC, Ribeiro CP, Victorio AM, Emanuelli T. Effect of different cooking methods on the oxidation, proximate and fatty acid composition of silver catfish (Rhamdia quelen) fillets. Food Chem 2008;106:140-6.

17. Thammapat P, Raviyan P, Siriamornpun S. Proximate and fatty acids composition of the muscles and viscera of Asian catfish (Pangasius bocourti). Food Chem 2010;122:223-7.

18. Ljubojevic D, Radosavljevic V, Pelic M, Dorđevic V, Zivkov Balos M, Cirkovi CM. Fatty acid composition, chemical composition and processing yield of traditional hot smoked common carp (Cyprinus carpio, L). Iran J Fish Sci 2016;15:1293-306.

19. Hara A, Radin NS. Lipid extraction of tissues with a low-toxicity solvent. Anal Biochem 1978;90:420-6.

20. Appelqvist L. Rapid methods of lipid extractions and fatty acid methyl ester preparation for seed and leaf tissue with special remarks on preventing the accumulation of lipids contaminants. Arkiv För Kemi RSAS 1968;28:551-70.

21. Jensen C, Lauridsen C, Bertelsen G. Dietary vitamin E: quality and storage a stability of pork and poultry. Trends Food Sci Technol 1998;9:62-72.

22. Mohamed DA, Hamed TE, Al-Okbi SY. Reduction in hypercholesterolemia and risk of cardiovascular diseases by mixtures of plant food extracts a study on plasma lipid profile, oxidative stress and testosterone in rats. Grasas Aceites 2010;61:378-89.

23. Fossati F, Prencipe L. Plasma triglycerides determined calorimetrically with an enzyme that produces hydrogenperoxide. Clin Chem 1982;28:2077-80.

24. Allain CC, Poon LS, Chan CS, Richmond W, Fu PC. Enzymatic determination of total serum cholesterol. Clin Chem 1974;20:470-5.

25. Friedewald WT, Levy RI, Fredrickson DS. Estimation of the concentration of low-density lipoprotein cholesterol in plasma without use of the preparative ultracentrifuge. Clin Chem 1972;18:499-502.

26. Retiman S, Frankel S. a colorimetric method for the determination of serum glutamic oxalacetic and glutamic pyruvic transaminases. Am J Clin Pathol 1957;28:56-63.

27. Tietz NW. Fundamentals of clinical chemistry. WB Saunders. Philadelphia, USA; 1976. p. 299.

28. Doumas BT, Watson WA, Biggs HG. Albumin standards and measurement of serum albumin with bromcresol green. Clin Chim Acta 1971;31:87-96.

29. Guler GO, Aktumsek A, Cakmak YS, Zengin G, Citil OB. Effect of season on fatty acid composition and $n-3 / n-6$ ratios of zander and carp muscle lipids in Altinapa Dam Lake. J Food Sci 2011;76:C594-7.

30. Molnar T, Kucska B, Szabo A, Biro J, Bercsenyi M, Hancz C. Effect of graded dietary fish oil supplementation on body composition and fillet fatty acid composition of pike (ESOX lucius L.). Acta Alimentaria 2012;41:86-93.

31. Zajic T, Mraz J, Sampels S, Pickova J. Fillet quality changes as a result of purging of common carp (Cyprinus carpio L.) with special regard to weight loss and lipid profile. Aquaculture 2013;400:111-9.

32. Li MH, Robinson EH, Tucker CS, Maning BB, Khoo L. Effect of dried algae Schizochytrium sp., a rich source of docosahexaenoic acid, on growth, fatty acid composition and sensory quality of channel catfish (Ictalurus punctatis). Aquaculture 2009;292:232-6.

33. Zhang Z, Liu L, Xie C, Li D, Xu J, Zhang M, et al. Lipid content, fatty acid profiles and nutrition quality of nine wild-caught freshwater fish species of the Yangtze Basin, China. J Food Nutr Res 2014;2:388-94.

34. Merdzhanova A, Dobreva D, Stancheva M. Quality evaluation of dietary lipid of Chanel catfish (Ictalurus punctatus) from Bulgaria. Bulg J Agric Sci 2015;21 Suppl 1:202-7.

35. Trbovic D, Markovic Z, Petronijevic R, Milijasevic M, Spiric D, Vranic D, et al. Changes in the proximate and fatty acid composition in carp meat during the semi-intensive farming. Tehnologija Mesa 2013;54:39-47.

36. Skalecki P, Florek M, Pyc A, Kaliniak A, Staszowska A. Comparison of physicochemical properties, fatty acid composition and mineral contents in common carp (Cyprinus carpio L.) fillet and the native traditional product carp Ham. Pol J Food Nutr Sci 2016;66:311-9.

37. Geri G, Poli BM, Gualtieri M, Lupi P, Parisi G. Body traits and chemical composition of muscle in the common carp (Cyprinus carpio L.) as influenced by age and rearing environment. Aquaculture 1995;129:329-33.

38. Bieniarz K, Koldras M, Kaminski J, Mejza T. Fatty acids and cholestorol in some freshwater fish species in poland. Folia Univ Agric Stetin 2000;27:21-44.

39. Kris-Etherton PM, Harris WS, Appel LJ. Fish consumption, fish oil, omega-3 fatty acids, and cardiovascular disease. Circulation 2002;106:2747-57.

40. Tocher D. Metabolism and functions of lipid and fatty acid in teleost fish. Rev Fish Sci 2003;11:107-84.

41. Steffens W. Freshwater fish-wholesome foodstuffs. Bulg J Agric Sci 2006;12:320-8.

42. Ozyurt G, Polat A, Loker GB. Vitamin and mineral content of pike perch (Sander lucioperca), common carp (Cyprinus carpio), and European catish (Silurus glanis). Turk J Vet Anim Sci 2009;33:351-6.

43. Stancheva M, Merdzhanova A, Dobreva DA, Makedonski L. Common carp (Cyprinus caprio) and European catfish (Sillurus glanis) from the danube river as sources of fat soluble vitamins and fatty acids. Czech J Food Sci 2014;32:16-24.

44. Szlinder-Richert J, Usydus Z, Malesa-Ciecwierz M, Polak-Juszczak L, Ruczynska W. Marine and farmed fish on the Polish market: comparison of the nutritive value and human exposure to PCDD/Fs and other contaminants. Chemosphere 2011;85:1725-33.

45. Hadjinikolova L. The influence of nutritive lipid sources on the growth and chemical and fatty acid composition of carp (Cyprinus carpio L.). Arch Pol Fish 2004;12:111-9.

46. Yang R, Le G, Li A, Zheng J, Shi Y. Effect of antioxidant capacity on blood lipid metabolism and lipoprotein lipase capacity of rats feed a high-fat diet. Nutrition 2006;22:1185-91. 
47. Da-Luz PL, Favarato D, Faria-Neto JR, Lemos P, Chagas AC. High ratio of triglycerides to HDL-cholesterol predicts extensive coronary disease. Clinics 2008;63:427-32.

48. Jawaid T, Argal S, Kamal M. Antidiabetic and antihyperlipidemic effects of the ethanolic extract of Alocasia indica rhizomes in high-fat diet/streptozotocin and streptozotocin/nicotinamide-induced type 2 diabetic rats. Asian J Pharm Clin Res 2015;8:58-62.

49. Kesh SB, Sarkar D, Manna K. High-fat diet-induced oxidative stress and its impact on metabolic syndrome: a review. Asian J Pharm Clin Res 2016;9:47-52.

50. Rizk MZ, Aly HF, Matloub AA, Fouad GI. The antihypercholesterolemic effect of ulvan polysaccharide extracted from the green alga Ulvafasciata on aged hypercholesterolemic rats. Asian J Pharm Clin Res 2016;9:165-76.

51. Kurushimaa H, Hayashi K, Toyota Y, Kambeb M, Kajiyama G. Comparison of hypocholesterolemic effects induced by dietary linoleic acid and oleic acid in hamsters. Atherosclerosis 1995;114:213-21

52. Binkoski AE, Kris-Etherton PM, Wilson TA, Mountain ML, Nicolosi RJ. The balance of unsaturated fatty acids is important to a cholesterol-lowering diet: comparison of mid-oleic sunflower oil and olive oil on cardiovascular disease risk factors. J Am Diet Assoc 2005; 105:1080-6.

53. Mente A, De Koning L, Shannon HS, Anand SS. A systematic review of the evidence supporting a causal link between dietary factors and coronary heart disease. Arch Intern Med 2009;169:659-69.

54. Bucher HC, Hengstler P, Schindler C, Meier G. N-3 polyunsaturated fatty acids in coronary heart disease: a metaanalysis of randomized controlled trials. Am J Med 2002; 112:298-304.
55. Mozaffarian D, Rimm EB. Fish intake, contaminants, and human health: evaluating the risks and the benefits. J Am Med Assoc 2006;296:1885-99.

56. Kondreddy RVK, Anikisetty M, Naidu KA. Medium-chain triglycerides and monounsaturated fatty acids potentiate the beneficial effects of fish oil on selected cardiovascular risk factors in rats. J Nutr Biochem 2016;28:91-102.

57. Punithavathi VR, Prince SM. Combined effects of quercetin and $\alpha$-tocopherol on lipids and glycoprotein components in isoproterenol-induced myocardial infarcted Wistar rats. Chem Biol Interact 2009;181:322-7.

58. Turner JD, Le NA, Brown WV. Effect of changing dietary fat saturation on low-density lipoprotein metabolism in man. Am J Physiol 1981;241:E57-63.

59. Craig WJ. Health-promoting properties of common herbs. Am J Clin Nutr 1999;70:491-9.

60. Jump JO, Clarke SD. Regulation of gene expression by dietary fat. Annu Rev Nutr 1999;19:63-90.

61. Daher CF, Baroody FG, Baroody MG. Effect of Urtica dioica extract intake upon blood lipid profile in the rats. Fitoterapia 2006;77:183-8.

62. Ramadan MF. Physalis peruviana pomace suppresses high cholesterol diet-induced hypercholesterolemia in rats. Grasas Aceites 2012;63:411-22.

63. Michelotti GA, Machado V, Diehl AM. NAFLD, NASH and liver cancer. Nat Rev Gastroenterol Hepatol 2013;10:656-65.

64. Mikolasevic I, Racki S, Bubic I, Jelic I, Stimac D, Orlic L. Chronic kidney disease and nonalcoholic Fatty liver disease proven by transient elastography. Kidney Blood Press Res 2013;37:305-10.

65. Armstrong MJ, Adams LA, Canbay A. Extrahepatic complications of the nonalcoholic fatty liver disease. Hepatology 2014;59:1174-97. 